\title{
CONGO GRASS GROWN IN ROTATION WITH SOYBEAN AFFECTS PHOSPHORUS BOUND TO SOIL CARBON ${ }^{(1)}$
}

\author{
Alexandre Merlin ${ }^{(2)}$, Zhenli L. He ${ }^{(3)}$ \& Ciro Antonio Rosolem ${ }^{(4)}$
}

\begin{abstract}
SUMMARY
The phosphorus supply to crops in tropical soils is deficient due to its somewhat insoluble nature in soil, and addition of $P$ fertilizers has been necessary to achieve high yields. The objective of this study was to examine the mechanisms through which a cover crop (Congo grass - Brachiaria ruziziensis) in rotation with soybean can enhance soil and fertilizer $P$ availability using long-term field trials and laboratory chemical fractionation approaches. The experimental field had been cropped to soybean in rotation with several species under no-till for six years. An application rate of no $\mathrm{P}$ or $240 \mathrm{~kg} \mathrm{ha}^{-1}$ of $\mathrm{P}_{2} \mathrm{O}_{5}$ had been applied as triple superphosphate or as Arad rock phosphate. In April 2009, once more 0.0 or $80.0 \mathrm{~kg} \mathrm{ha}^{-1}$ of $\mathrm{P}_{2} \mathrm{O}_{5}$ was applied to the same plots when Congo grass was planted. In November 2009, after Congo grass desiccation, soil samples were taken from the 0-5 and 5-10 cm depth layer and soil $P$ was fractionated. Soil-available $P$ increased to the depth of $10 \mathrm{~cm}$ through growing Congo grass when $P$ fertilizers were applied. The C:P ratio was also increased by the cover crop. Congo grass cultivation increased $P$ content in the soil humic fraction to the depth of $10 \mathrm{~cm}$. Congo grass increases soil $P$ availability by preventing fertilizer from being adsorbed and by increasing soil organic $P$.
\end{abstract}

Index terms: crop rotation, no-till, organic $\mathrm{P}$, phosphorus fractionation.

RESUMO: Brachiaria ruziziensis CULTIVADA EM ROTAÇÃO COM SOJA INTERFERE NO FÓSFORO LIGADO AO CARBONO DO SOLO

O fornecimento de P para as culturas em solos tropicais é deficiente em razão da sua natureza pouco solúvel no solo; e a adição de fertilizantes fosfatados é necessária para obter-se alta produtividade. O objetivo deste estudo foi examinar os mecanismos pelos quais uma planta de cobertura (Braquiária - Brachiaria ruziziensis) cultivada em rotação com soja

(1) Received for publication on July 9, 2013 and approved on March 26, 2014.

(2) Field Production Supervisor, Monsanto. Rua Eduardo Oliveira, 940. CEP 38400-174 Uberlândia (MG), Brazil. E-mail: Alexandre.merlin@monsanto.com

(3) Professor, University of Florida, IFAS, Indian River Research and Education Center. Fort Pierce, Florida 34945-3138, USA. Email: zhe@ufl.edu

(4) Professor, College of Agricultural Sciences, Department of Crop Science, Universidade Estadual Paulista. Postal Box 237. CEP 18603-970 Botucatu (SP), Brazil. Holder of 1A Scholarship from the CNPq. E-mail: rosolem@fca.unesp.br 


\begin{abstract}
pode melhorar a disponibilidade do $P$ de fertilizantes e do solo, utilizando ensaios de campo de longo prazo e abordagens de laboratório com fracionamento químico do $P$. $O$ campo experimental vinha sendo cultivado com soja em rotação com diversas espécies sob semeadura direta há seis anos. Doses de 0 ou $240 \mathrm{~kg} \mathrm{ha}^{-1}$ de $\mathrm{P}_{2} \mathrm{O}_{5}$, como superfosfato triplo ou fosfato reativo de Arad, haviam sido aplicadas. Em abril de 2009, foram aplicados novamente 0 e 80 $\mathrm{kg} \mathrm{ha}^{-1}$ de $\mathrm{P}_{2} \mathrm{O}_{5}$, às mesmas parcelas, quando foi semeada B. ruziziensis. Em novembro de 2009, após a dessecação da braquiária, amostras de solo foram coletadas nas camadas de $0-5$ e $5-10 \mathrm{~cm}$, e o $P$ foi fracionado. $O P$ disponível do solo aumentou em profundidade com o cultivo de $\mathrm{B}$. ruziziensis na presença de fertilizantes fosfatados. A relação $C / P$ também foi aumentada pela planta de cobertura. O cultivo de B. ruziziensis elevou os teores de P na fração húmica do solo. A B. ruziziensis aumenta a disponibilidade de $P$ no solo por prevenir a fixação do Paplicado como fertilizante e manter o P em formas orgânicas.
\end{abstract}

Termos de indexação: fracionamento do $P$, fósforo orgânico, rotação de culturas, semeadura direta.

\section{INTRODUCTION}

The low efficiency of phosphorus use by crops in tropical soils is mostly due to soil P-fixation through adsorption or precipitation reactions. The somewhat insoluble nature of soil $\mathrm{P}$ impairs crop yields, and additional $\mathrm{P}$ sources must be applied as fertilizers in order to achieve high crop yields. One potential approach is to adopt cropping systems that may increase the level of plant-available P in soil. Cropping systems that utilize green and animal manures have had a positive impact on crop yields and reduce dependence on chemical fertilizers. Organic amendments can directly affect soil $\mathrm{P}$ availability through interaction with soil components.

From 30 to $50 \%$ of total soil $\mathrm{P}$ is organic $\mathrm{P}$, appearing mainly as phytates, nucleic acids (and their derivatives), and phospholipids. Some of this organic $\mathrm{P}$ is contained in or originates from crop residues. Therefore, returning crop residues to the soil is important in $\mathrm{P}$ cycling. In a 16 -week soil incubation study, Reddy et al. (2001) observed that soybean (Glycine max L.) and wheat (Triticum aestivum L.) residues favored build-up of labile inorganic and organic $\mathrm{P}$ at the expense of recalcitrant P. In field studies, crop residues applied together with rock phosphate resulted in increased soil $\mathrm{P}$ availability, increased cereal $\mathrm{P}$ uptake, and higher yields than application of rock phosphate alone (Waigwa et al., 2003). Similarly, Essington \& Howard (2000) reported that plots under no-till had significantly higher values of organic $\mathrm{P}$ than those under conventional tillage.

To become available to plants, organic $\mathrm{P}$ must be mineralized. Hence, the availability of $\mathrm{P}$ held in the soil microbial biomass, or in plant residues, depends on the disruption of protecting cell structures. Mineralization of organic $\mathrm{P}$ is mediated by soil microorganisms, but the rate and pattern is regulated by environmental conditions and residue quality. Changes in both soil moisture and temperature affect microbial activity and thereby $\mathrm{P}$ mineralization. Net $\mathrm{P}$ mineralization is often positively correlated with residue $\mathrm{P}$ concentration and negatively correlated with $\mathrm{C}: \mathrm{P}$ ratio (Kwabiah et al., 2003) and lignin concentration or lignin/P ratio (Lupwayi et al., 2004). Whitbread et al. (2000) observed greater $\mathrm{P}$ content in wheat where legume residues had been retained, as compared with plots where they had been removed, and in a greenhouse experiment, a greater sorghum biomass following cover crops was reported three out of four times (Cavigelli \& Thien, 2003). The exudation of organic acids and $\mathrm{P}$ mobilization by phosphatases were described as mechanisms by which white lupin could solubilize soil P (Klose \& Tabatabai, 2002). A significant population of microorganisms shows ability for organic phosphorus mineralization, but a restrictive effect of Cajanus cajan was observed on the bacterial and fungal producers of alkaline and acid phosphatases, whose numbers were always lower than those obtained with Brachiaria ruziziensis (Nahas, 2002).

Congo grass (Brachiaria ruziziensis) has been widely used in crop rotation and crop-livestock integrated systems in Brazil because of its good adaptation to low fertility soils, high yield potential, and good forage quality (Garcia et al., 2008). This grass may have a positive effect on soil $\mathrm{P}$ availability, resulting from the influence of organic acids on $\mathrm{P}$ sorption, since it can exude citrate or oxalate under low pH conditions (Louw-Gaume et al., 2010) and decrease the maximum adsorption capacity of $\mathrm{P}$ in the soil (Janegitz et al., 2013). In addition, the activities of root acid phosphatases and phytases of Congo grass were higher under conditions of low $\mathrm{P}$ supply (Merlin et al., 2009).

Hence, the introduction of Congo grass in a cropping system may favor $\mathrm{P}$ solubilization, or decrease soil $\mathrm{P}$ adsorption (George et al., 2006; Janegitz et al., 2013), resulting in higher P use efficiency. The objective of this study was to evaluate the effectiveness of Congo grass (B. ruziziensis) grown as a cover crop in enhancing soil $\mathrm{P}$ availability and its relationship to $\mathrm{C}$ behavior using long-term field trials and laboratory chemical fractionation approaches. 


\section{MATERIAL AND METHODS}

The long-term field trial site is located in Botucatu, São Paulo, Brazil (22 $51^{\circ}$ 'S, $48^{\circ} 26^{\prime} \mathrm{W}$ Grw and altitude of $840 \mathrm{~m}$ ). The soil is a Rhodic Hapludox (Soil Survey Staff, 2010) with $670 \mathrm{~g} \mathrm{~kg}^{-1}$ of sand and $210 \mathrm{~g} \mathrm{~kg}^{-1}$ of clay. Selected chemical characteristics of the soil are shown in table 1 . The crop rotation system was first established in 1998 and consisted of triticale (X Tritico secale Wittmack) and black oat (Avena stringosa) grown in autumn-winter, pearl millet (Pennisetum glaucum) grown in the spring, and soybean (Glycine $\max$ ) in the summer. In 1998 and 2001 the experiment received 0 (control) and $80 \mathrm{~kg} \mathrm{ha}^{-1}$ of $\mathrm{P}_{2} \mathrm{O}_{5}$ (total $\mathrm{P}$ ) either as triple superphosphate or as Arad reactive rock phosphate. The impact of Congo grass ( $B$. ruziziensis) has been studied since 2006 , when the rotation was changed from triticale, black oat, or pearl millet to Congo grass. In 2006 and 2009, the treatments consisted of 0 and $80 \mathrm{~kg} \mathrm{ha}^{-1}$ of $\mathrm{P}_{2} \mathrm{O}_{5}$, which was applied as triple superphosphate (soluble) or as natural Arad rock phosphate (reactive) to the same plots which had previously received the same fertilizers. Triple superphosphate had $180 \mathrm{~g} \mathrm{~kg}^{-1}$ of $\mathrm{P}$, $79 \mathrm{~g} \mathrm{~kg}^{-1}$ of $\mathrm{Ca}$, and $12 \mathrm{~g} \mathrm{~kg}^{-1}$ of S; and reactive Arad phosphate had $143 \mathrm{~g} \mathrm{~kg}^{-1}$ of $\mathrm{P}, 269 \mathrm{~g} \mathrm{~kg}^{-1}$ of Ca, and $8.5 \mathrm{~g} \mathrm{~kg}^{-1}$ of S. In April 2009, the P fertilizers were applied on the soil surface, and Congo grass was planted (without K or $\mathrm{N}$ fertilizer) in half of the plots at $30 \mathrm{~kg} \mathrm{ha}^{-1}$ of seeds ( $42 \%$ viable seeds) and desiccated 289 days after emergence (DAE) using glyphosate at $2.88 \mathrm{~kg} \mathrm{ha}^{-1}$ (a.i.). In plots without Congo grass, glyphosate was applied twice to prevent weed growth.

In order to estimate Congo grass dry matter yields, plant residues were sampled at six randomized sites per plot using a $0.25 \mathrm{~m}^{2}(0.5 \times 0.5 \mathrm{~m})$ wooden frame and were dried in a forced air oven at $60^{\circ} \mathrm{C}$ for $72 \mathrm{~h}$. The plant samples were weighed and sub-samples were analyzed for $\mathrm{N}, \mathrm{P}, \mathrm{K}, \mathrm{Ca}$, and $\mathrm{Mg}$ concentrations. The remaining material was returned to its original site. Nitrogen in plant samples was determined by sulfuric acid digestion and steam distillation, and $\mathrm{P}$, $\mathrm{K}, \mathrm{Ca}$, and $\mathrm{Mg}$ were determined using atomic absorption spectrometry (AA-7000, Shimadzu Scientific Instruments, Japan) after wet acid digestion.

In November 2009, six soil samples were randomly collected with an auger at two depths $(0-5$ and $5-10 \mathrm{~cm})$ from each plot and combined into one composite sample per depth for analysis. Soil $\mathrm{pH}$ was determined in $0.01 \mathrm{~mol} \mathrm{~L}^{-1} \mathrm{CaCl}_{2}$ at a $1: 2.5$ soil:solution $(\mathrm{w} / \mathrm{v})$ ratio using a $\mathrm{pH}$-meter (DM-22, Digimed, Brazil), and available $\mathrm{P}$ was extracted by the pearl resin method as described in Raij et al. (1986).

Organic $\mathrm{C}$ concentration in the soil samples was determined by dry combustion using a C/N Analyzer (Vario Max Macro Elemental Analyzer, Elemental Analysis System GmbH, Hanau, Germany) at the University of Florida Indian River Research and Education Center in Fort Pierce, FL. Soil organic P fractionation was conducted according to Bowman \& Cole (1978), modified by Sharpley \& Smith (1985) and Ivanoff et al. (1998). In order to estimate labile organic $\mathrm{P}, 0.5 \mathrm{~g}$ of soil was shaken in a water suspension for $16 \mathrm{~h}$ on a horizontal shaker (end-over-end) with $0.5 \mathrm{~mol} \mathrm{~L}^{-1} \mathrm{NaHCO}_{3}(\mathrm{pH}$ 8.5). Inorganic $\mathrm{P}(\mathrm{Pi})$ and total $\mathrm{P}(\mathrm{Pt})$ were determined in the extract, and labile organic $\mathrm{P}$ was calculated as the difference between them. Moderately labile organic $\mathrm{P}$ was determined by the difference between Pi and Pt extracted with $1.0 \mathrm{~mol} \mathrm{~L}^{-1} \mathrm{HCl}$. Organic $\mathrm{P}$ bound to fulvic $(\mathrm{Pf})$ and humic $(\mathrm{Ph})$ substances was extracted with $0.5 \mathrm{~mol} \mathrm{~L}^{-1}$ $\mathrm{NaOH}$. To separate $\mathrm{Pf}$ from $\mathrm{Ph}$, an aliquot of the $0.5 \mathrm{~mol} \mathrm{~L}^{-1} \mathrm{NaOH}$ extract was taken and acidified to $\mathrm{pH}$ 1.0-1.5 with concentrated $\mathrm{HCl}$. At this $\mathrm{pH}$, humic acids precipitate, and fulvic acids remain in the solution. $\mathrm{Pt}$ in the acidified sample is a measure of $\mathrm{Pf}$. The $\mathrm{Ph}$ fraction was determined by subtracting $\mathrm{Pf}$ from the Pt measured in the $0.5 \mathrm{~mol} \mathrm{~L}^{-1} \mathrm{NaOH}$ extract. Phosphorus concentration in the solutions was determined by colorimetric analysis by the molybdateblue/ascorbic acid method (Murphy \& Riley, 1962). All samples were analyzed in triplicate. Carbon concentration in the extracts containing fulvic and humic substances was determined by a Liquid Total Organic Carbon Analyzer (liquid TOC trace, Elemental Analysis System GmbH, Hanau, Germany). Carbon to $\mathrm{P}$ ratio $(\mathrm{C}: \mathrm{P})$ was calculated using the values obtained from the analyses described above.

The experimental design was a $3 \times 2$ factorial arrangement with three initial $\mathrm{P}$ treatments, with and without Congo grass, and four replications for each treatment. Data for each soil depth were analyzed separately. Plots were $5.0 \times 8.0 \mathrm{~m}$. Results were subjected to statistical analyses using SAS - System for Windows 9.2 (SAS, 2001) through the GLM procedure, and means were compared by LSD $(p<0.05)$.

\section{RESULTS}

The average dry matter yield of Congo grass was significantly increased by $\mathrm{P}$ fertilizers (Table 2), irrespective of $\mathrm{P}$ sources. Phosphorus concentrations

Table 1. Soil chemical and particle size characteristics at the time the experiment was set up (1998)

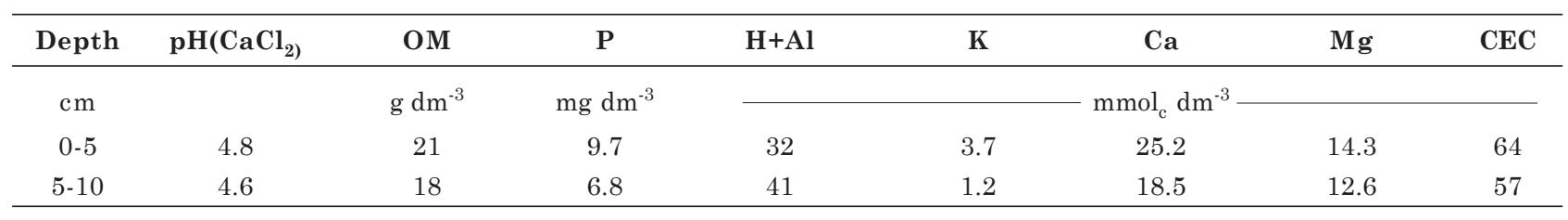


in plant tissue were also increased by $\mathrm{P}$ fertilization (Table 2), but were higher for the soluble source.

The average concentrations of $\mathrm{N}, \mathrm{K}, \mathrm{Ca}$, and $\mathrm{Mg}$ in plant tissue were 13.7, 20.1, 7.8, and $5.2 \mathrm{~g} \mathrm{~kg}^{-1}$, respectively, without significant differences due to $\mathrm{P}$ fertilization. These nutrient concentrations are within the adequate range, showing that there was no nutrient deficiency other than $\mathrm{P}$ during the experiment.

Soil inorganic available $\mathrm{P}$ (resin-P) was increased by Congo grass at both depths in $\mathrm{P}$ fertilized plots (Table 3), and no difference was observed between the two $\mathrm{P}$ sources. Moreover, the cover crop increased organic $\mathrm{P}$ extractable by $0.5 \mathrm{~mol} \mathrm{~L}^{-1} \mathrm{NaHCO}_{3}$ at the $0-5 \mathrm{~cm}$ depth of plots receiving soluble or reactive $\mathrm{P}$ fertilizer, but had no effect on organic $\mathrm{P}$ or resin- $\mathrm{P}$ for the plots without $\mathrm{P}$ fertilizers (Table 3 ). No differences in $1.0 \mathrm{~mol} \mathrm{~L}^{-1} \mathrm{HCl}$ extractable $\mathrm{P}$ were observed.

Humic substance bound organic $\mathrm{P}(\mathrm{Ph})$ contents in soils from Congo grass fertilized plots were significantly higher than those without the cover crop (Table 3). With the cover crop, P fertilization increased $\mathrm{Ph}$ at the 0-5 and 5-10 $\mathrm{cm}$ depth. Fulvic substance bound organic $\mathrm{P}(\mathrm{Pf})$ was not affected by $\mathrm{P}$ sources or the cover crop.

Table 2. Mean values of Brachiaria ruziziensis dry matter and phosphorus content under broadcast application of phosphorus sources and $B$. ruziziensis

\begin{tabular}{ccc}
\hline Treatment & Dry Matter & P content \\
\hline $\mathrm{kg} \mathrm{ha}^{-1}$ of $\mathrm{P}$ & $\mathrm{kg} \mathrm{ha}^{-1}$ & $\mathrm{~g} \mathrm{~kg}^{-1}$ \\
0 & $3142 \mathrm{~b}$ & $0.73 \mathrm{c}$ \\
$35 \mathrm{RP}^{(1)}$ & $3524 \mathrm{a}$ & $1.15 \mathrm{~b}$ \\
$35 \mathrm{SP}^{(2)}$ & $3855 \mathrm{a}$ & $1.58 \mathrm{a}$ \\
\hline
\end{tabular}

${ }^{(1)} \mathrm{RP}$ : Reactive Phosphate; ${ }^{(2)}$ SP: Superphosphate. Different letters in the columns show significant differences (LSD, $p>0.05$ ).
The $\mathrm{P}$ sources and the cover crop increased organic $\mathrm{P}$ pools and consequently affected total organic $\mathrm{P}$ content in the soil. The highest content was observed for soluble phosphate with $B$. ruziziensis cultivation at the $0-5 \mathrm{~cm}$ depth (Table 3 ).

Cover crop treatment had the greatest influence on soil $\mathrm{C}$ fractions, regardless of the rate or source of $\mathrm{P}$ fertilizers (Table 4). Growing Congo grass also increased the $\mathrm{C}$ content in the humic fraction at both depths (Table 4). The highest $\mathrm{C}$ content of the humic fraction was found in the soil receiving rock reactive phosphate at the $0-5 \mathrm{~cm}$ depth. An increase in the $\mathrm{C}: \mathrm{P}$ ratio $(\mathrm{p}=0.05)$ was observed in plots under Congo grass (Table 5), regardless of soil depth. The humic fraction C:P ratio was also higher in plots planted to Congo grass, regardless of soil depth.

\section{DISCUSSION}

The original soil $\mathrm{P}$ level was inadequate for Congo grass growth since there was response in the average dry matter yield. Corrêa \& Haag (1993) emphasized the importance of $\mathrm{P}$ supply for grasses in the first year of cropping in Brazilian soils. Brachiaria decumbens has been recommended for low $\mathrm{P}$ soils since this species is well adapted, and in some cases it can produce three times more dry matter than other Brachiaria. Hence, Congo grass may not be well adapted to soils with low $\mathrm{P}$ availability. However, dry matter yield differences among Brachiaria species were not observed at high P supply (Corrêa \& Haag, 1993). The same authors observed a decrease in $\mathrm{P}$ fertilization response after the second crop of the Brachiaria genus in the same area, probably due to higher access to native $\mathrm{P}$ in the soil.

Table 3. Mean values of available $\mathbf{P}$ (P-resin), labile organic $\mathbf{P}\left(0.5\right.$ mol L-1 $\left.\mathrm{NaHCO}_{3}\right)$, moderately labile organic $\mathrm{P}\left(1.0 \mathrm{~mol} \mathrm{~L}^{-1} \mathrm{HCl}\right)$, humic substance bound organic $\mathrm{P}(\mathrm{Ph})$, fulvic substance bound organic $\mathrm{P}$ (Pf), and total organic $\mathrm{P}(\mathrm{Pt})$ levels in the soil at the 0-5 and 5-10 cm depths under broadcast application of phosphorus sources and Brachiaria ruziziensis (presence - with; absence - without)

\begin{tabular}{|c|c|c|c|c|c|c|c|c|c|c|c|c|}
\hline \multirow{2}{*}{ Treatment } & \multicolumn{2}{|c|}{ Resin } & \multicolumn{2}{|c|}{$0.5 \mathrm{~mol} \mathrm{~L}^{-1} \mathrm{NaHCO}_{3}$} & \multicolumn{2}{|c|}{$1.0 \mathrm{~mol} \mathrm{~L}^{-1} \mathrm{HCl}$} & \multicolumn{2}{|c|}{$\mathbf{P h}$} & \multicolumn{2}{|c|}{ Pf } & \multicolumn{2}{|c|}{$\mathrm{Pt}$} \\
\hline & With & Without & With & Without & With & Without & With & Without & With & Without & With & Without \\
\hline \multirow[t]{2}{*}{$\mathrm{kg} \mathrm{ha}^{-1}$ of $\mathrm{P}$} & \multicolumn{12}{|c|}{$\mathrm{mg} \mathrm{dm}{ }^{-3}$} \\
\hline & \multicolumn{12}{|c|}{$0-5 \mathrm{~cm}$} \\
\hline 0 & $30.1 \mathrm{~b}$ & $34.9 \mathrm{a}$ & $22.6 \mathrm{a}$ & $13.1 \mathrm{~b}$ & $25.6 \mathrm{a}$ & $28.0 \mathrm{a}$ & $36.8 \mathrm{~b}$ & $49.2 \mathrm{a}$ & $15.1 \mathrm{a}$ & $14.4 \mathrm{a}$ & $111.5 \mathrm{a}$ & $119.8 \mathrm{a}$ \\
\hline $35 \mathrm{RP}^{(1)}$ & $60.9 \mathrm{a}$ & $56.1 \mathrm{~b}$ & $17.6 \mathrm{a}$ & $12.5 \mathrm{~b}$ & $31.9 \mathrm{a}$ & $28.6 \mathrm{a}$ & $44.3 \mathrm{a}$ & $38.6 \mathrm{~b}$ & $13.7 \mathrm{a}$ & $18.3 \mathrm{a}$ & $103.1 \mathrm{a}$ & $96.0 \mathrm{~b}$ \\
\hline \multirow[t]{2}{*}{$35 \mathrm{SP}^{(2)}$} & $54.4 \mathrm{a}$ & $47.1 \mathrm{~b}$ & $21.0 \mathrm{a}$ & $15.2 \mathrm{~b}$ & $21.6 \mathrm{a}$ & $26.5 \mathrm{a}$ & $46.3 \mathrm{a}$ & $34.3 \mathrm{~b}$ & $17.8 \mathrm{a}$ & $16.7 \mathrm{a}$ & $109.2 \mathrm{a}$ & $96.1 \mathrm{~b}$ \\
\hline & \multicolumn{12}{|c|}{$5-10 \mathrm{~cm}$} \\
\hline 0 & $20.5 \mathrm{a}$ & $24.5 \mathrm{a}$ & $15.7 \mathrm{a}$ & $14.5 \mathrm{a}$ & $21.8 \mathrm{a}$ & $19.7 \mathrm{a}$ & $43.0 \mathrm{a}$ & $43.7 \mathrm{a}$ & $23.0 \mathrm{a}$ & $21.8 \mathrm{a}$ & $112.6 \mathrm{a}$ & $98.1 \mathrm{~b}$ \\
\hline $35 \mathrm{RP}^{(1)}$ & $48.8 \mathrm{a}$ & $34.9 \mathrm{~b}$ & $18.7 \mathrm{a}$ & $16.4 \mathrm{~b}$ & $28.5 \mathrm{a}$ & $26.7 \mathrm{a}$ & $42.1 \mathrm{a}$ & $37.3 \mathrm{~b}$ & $22.9 \mathrm{a}$ & $21.7 \mathrm{a}$ & $106.8 \mathrm{a}$ & $99.5 \mathrm{~b}$ \\
\hline $35 \mathrm{SP}^{(2)}$ & $37.8 \mathrm{a}$ & $19.0 \mathrm{~b}$ & $18.2 \mathrm{a}$ & $13.7 \mathrm{~b}$ & $17.3 \mathrm{a}$ & $16.8 \mathrm{a}$ & $45.4 \mathrm{a}$ & $32.4 \mathrm{~b}$ & $25.4 \mathrm{a}$ & $23.2 \mathrm{a}$ & $106.8 \mathrm{a}$ & $94.4 \mathrm{~b}$ \\
\hline
\end{tabular}

(1) RP: Reactive Phosphate; ${ }^{(2)}$ SP: Superphosphate. Different letters in rows show significant differences between Congo grass treatments $(\mathrm{p}<0.05)$. 
Table 4. Mean values of dissolved carbon in the extractant 0.5 mol L-1 $\mathrm{NaOH}$ in the humic fraction (Humic C), fulvic fraction (Fulvic - C) and Total (Total - C) in the soil at 0-5 and 5-10 cm depths under broadcast application of phosphorus sources and Brachiaria ruziziensis (presence - with; absence - without)

\begin{tabular}{|c|c|c|c|c|c|c|}
\hline \multirow{2}{*}{ Treatment } & \multicolumn{2}{|c|}{ Humic - C } & \multicolumn{2}{|c|}{ Fulvic - C } & \multicolumn{2}{|c|}{ Total - C } \\
\hline & With & Without & With & Without & With & Without \\
\hline \multirow[t]{2}{*}{$\mathrm{kg} \mathrm{ha}^{-1}$ of $\mathrm{P}$} & \multicolumn{6}{|c|}{$-\mathrm{g} \mathrm{kg}^{-1}$} \\
\hline & \multicolumn{6}{|c|}{$0-5 \mathrm{~cm}$} \\
\hline 0 & $0.967 \mathrm{a}$ & $0.857 \mathrm{~b}$ & $0.208 \mathrm{a}$ & $0.195 \mathrm{a}$ & $1.175 \mathrm{a}$ & $1.052 \mathrm{~b}$ \\
\hline $35 \mathrm{RP}^{(1)}$ & $1.001 \mathrm{a}$ & $0.797 \mathrm{~b}$ & $0.186 \mathrm{a}$ & $0.194 \mathrm{a}$ & $1.196 \mathrm{a}$ & $0.983 \mathrm{~b}$ \\
\hline \multirow[t]{2}{*}{$35 \mathrm{SP}^{(2)}$} & $0.884 \mathrm{a}$ & $0.759 \mathrm{~b}$ & $0.209 \mathrm{a}$ & $0.171 \mathrm{~b}$ & $1.093 \mathrm{a}$ & $0.930 \mathrm{~b}$ \\
\hline & \multicolumn{6}{|c|}{$5-10 \mathrm{~cm}$} \\
\hline 0 & $0.738 \mathrm{a}$ & $0.558 \mathrm{~b}$ & $0.182 \mathrm{a}$ & $0.187 \mathrm{a}$ & $0.921 \mathrm{a}$ & $0.744 \mathrm{~b}$ \\
\hline $35 \mathrm{RP}^{(1)}$ & $0.731 \mathrm{a}$ & $0.569 \mathrm{~b}$ & $0.186 \mathrm{a}$ & $0.184 \mathrm{a}$ & $0.918 \mathrm{a}$ & $0.755 \mathrm{~b}$ \\
\hline $35 \mathrm{SP}^{(2)}$ & $0.638 \mathrm{a}$ & $0.481 \mathrm{~b}$ & $0.183 \mathrm{a}$ & $0.179 \mathrm{a}$ & $0.821 \mathrm{a}$ & $0.661 \mathrm{~b}$ \\
\hline
\end{tabular}

(1) RP: Reactive Phosphate; ${ }^{(2)}$ SP: Superphosphate. Different letters in the rows show significant differences ( $>0.05$ ).

Table 5. Mean values of the carbon and phosphorus (C:P) ratio in the soil at 0-5 and 5-10 cm depths under broadcast application of phosphorus sources and Brachiaria ruziziensis (presence - with; absence without)

\begin{tabular}{|c|c|c|c|c|c|c|}
\hline \multirow{2}{*}{ Treatment } & \multicolumn{2}{|c|}{ C:P } & \multicolumn{2}{|c|}{ Humic - C:P } & \multicolumn{2}{|c|}{ Fulvic - C:P } \\
\hline & With & Without & With & Without & With & Without \\
\hline \multirow[t]{2}{*}{$\mathrm{kg} \mathrm{ha} \mathrm{A}^{-1}$ of $\mathrm{P}$} & & & \multicolumn{2}{|c|}{$-\mathrm{g} \mathrm{kg}^{-1}$} & & \\
\hline & \multicolumn{6}{|c|}{$0-5 \mathrm{~cm}$} \\
\hline 0 & $94.8 \mathrm{a}$ & $75.9 \mathrm{~b}$ & $133.5 \mathrm{a}$ & $92.4 \mathrm{~b}$ & $40.6 \mathrm{a}$ & $42.7 \mathrm{a}$ \\
\hline $35 \mathrm{RP}^{(1)}$ & $84.3 \mathrm{a}$ & $66.6 \mathrm{~b}$ & $113.0 \mathrm{a}$ & $85.3 \mathrm{~b}$ & $36.5 \mathrm{a}$ & $34.1 \mathrm{a}$ \\
\hline \multirow[t]{2}{*}{$35 \mathrm{SP}^{(2)}$} & $79.3 \mathrm{a}$ & $72.5 \mathrm{a}$ & $103.3 \mathrm{a}$ & $104.6 \mathrm{a}$ & $39.3 \mathrm{a}$ & $38.7 \mathrm{a}$ \\
\hline & \multicolumn{6}{|c|}{$5-10 \mathrm{~cm}$} \\
\hline 0 & $90.7 \mathrm{a}$ & $65.9 \mathrm{~b}$ & $141.8 \mathrm{a}$ & $80.1 \mathrm{~b}$ & $39.4 \mathrm{a}$ & $41.6 \mathrm{a}$ \\
\hline $35 \mathrm{RP}^{(1)}$ & $81.1 \mathrm{a}$ & $65.1 \mathrm{~b}$ & $118.0 \mathrm{a}$ & $89.3 \mathrm{~b}$ & $36.0 \mathrm{a}$ & $36.9 \mathrm{a}$ \\
\hline $35 \mathrm{SP}^{(2)}$ & $71.0 \mathrm{a}$ & $69.8 \mathrm{a}$ & $99.1 \mathrm{a}$ & $88.2 \mathrm{~b}$ & $35.9 \mathrm{a}$ & $33.8 \mathrm{a}$ \\
\hline
\end{tabular}

(1) RP: Reactive Phosphate; (2) SP: Superphosphate. Different letters in the rows show significant differences between Congo grass treatments $(\mathrm{p}<0.05)$.

Phosphorus concentration in plant tissue was significantly higher due to $\mathrm{P}$ fertilization, and an even higher concentration was observed with the soluble $\mathrm{P}$ source. Similar results were found by Corrêa \& Haag (1993) studying critical levels of $\mathrm{P}$ for the establishment of pasture grass on a Red Yellow Oxisol. Phosphorus accumulation in plant tissue may vary by species. This characteristic is important in deciding on which crop to use as a cover crop since the ability to accumulate nutrients plus the ability of adaptation to low fertility can determine the success of $\mathrm{P}$ cycling in the system.

Growing Congo grass increased soil available $\mathrm{P}$ as estimated by resin extraction at both soil depths when $\mathrm{P}$ fertilizers were applied. The buildup of available $\mathrm{P}$ in the topsoil by B. ruziziensis cropped under no-till supports the findings of several other studies, including other species (Galvani et al., 2008). This effect may result from the influence of organic acids on $\mathrm{P}$ sorption, since Brachiarias can exude citrate or oxalate (Watts \& Evans, 2003; Louw-Gaume et al., 2010), and Congo grass was shown to decrease the soil maximum P adsorption capacity (Janegitz et al., 2013). In addition, the activities of acid phosphatases and phytases released by the roots or microorganisms of some grasses such as Congo grass are higher under low P supply conditions (Merlin et al., 2009), and this is paramount in solubilizing $\mathrm{P}$ in the soil. Findings of Louw-Gaume et al. (2010) support the hypothesis that Brachiaria roots can modify their $\mathrm{P}$ acquisition capacity by adjusting their physiological, morphological, and architectural traits to meet changes in plant $\mathrm{P}$ demand. These findings are supported by other authors (Merlin et al., 2009) who reported that root tissue activity of alkaline phosphatases and phytases of Brachiaria ruziziensis and $B$. decumbens were higher with low $\mathrm{P}$ supply. 
However, in the present experiment, in low $\mathrm{P}$ plots there was a significant effect of Congo grass on $\mathrm{P}$ availability. Hence, in the presence of $\mathrm{P}$ fertilization, the role of the cover crop in avoiding $\mathrm{P}$ adsorption to soil colloids seems to be more important.

Soil organic P may be utilized by plants after mineralization and subsequent release of Pi. Some root exudates, such as acid phosphatase, which catalyzes hydrolytic cleavage of the C-O-P ester bond of organic P present in the soil (Eivazi \& Tabatabai, 1977) and releases $\mathrm{P}$ as plant-available $\mathrm{Pi}$ forms $\left(\mathrm{H}_{2} \mathrm{PO}_{4}^{-}, \mathrm{HPO}_{4}{ }^{2-}\right)$, may originate from plant and soil microorganisms. In most agricultural soils, organic $\mathrm{P}$ forms comprise $20-85 \%$ of total $\mathrm{P}$, of which the largest fraction (50\%) appears to be in the form of phytin and its derivatives (Dalal, 1977). Organic P forms such as phytin, lecithin, and glycophosphate may be important in the $\mathrm{P}$ nutrition of plants (Tarafdar \& Claassen, 1988). In this experiment, Congo grass increased some organic $\mathrm{P}$ forms. The greatest increase was observed in the $0.5 \mathrm{~mol} \mathrm{~L}^{-1} \mathrm{NaHCO}_{3}$ fraction at the $0-5 \mathrm{~cm}$ depth of plots receiving soluble or reactive $\mathrm{P}$ fertilizer. This effect may be explained by root activity since there is evidence that enhanced phosphatase activity in the rhizosphere is implicated in the depletion of organic $\mathrm{P}$ forms from $\mathrm{P}$-deficient Oxisols (George et al., 2006).

The $0.5 \mathrm{~mol} \mathrm{~L}^{-1} \mathrm{NaHCO}_{3}$ fraction, though not directly taken up by plants, is generally considered to be readily or potentially available because of its low molecular weight and because it can be readily mineralized (Hedley et al., 1982). The increase in the $0.5 \mathrm{~mol} \mathrm{~L}^{-1} \mathrm{NaHCO}_{3}$ fraction is in accordance with the increased available $\mathrm{P}$, showing that Congo grass can enhance $\mathrm{P}$ availability in high P-fixing soils. A linear relationship between acid phosphatase activity and the release of inorganic $\mathrm{P}$ from different organic $\mathrm{P}$ forms has been observed, which could be a mechanism to explain this increase in the $0.5 \mathrm{~mol} \mathrm{~L}^{-1}$ $\mathrm{NaHCO}_{3}$ fraction (Tarafdar, 1989). Interestingly, Congo grass increased humic substance bound organic $\mathrm{P}(\mathrm{Ph})$ contents in soils from fertilized plots. The increase in $\mathrm{pH}$ has a big effect on $\mathrm{P}$ availability since $\mathrm{P}$ in these humic fractions has been suggested to represent a moderately to highly resistant $\mathrm{P}$ pool in soils (Bowman \& Cole, 1978). Knowledge of its chemical nature seems essential for an understanding of its role in $\mathrm{P}$ cycling. Makarov et al. (1996), who investigated the $\mathrm{P}$-species distribution in humic fractions from $\mathrm{A}$ horizons, reported that the labile $\mathrm{P}$ in humic fractions indicate limited microbial activity, resulting in accumulation of organic $\mathrm{P}$ forms. Indirectly, the organic $\mathrm{P}$ accumulation observed in the same treatments could be a side effect of the higher content of $\mathrm{P}$ in humic substances. In line with these findings, Hong \& Yamane (1980) found that $60 \%$ of the organic $\mathrm{P}$ fractions in fulvic acid were found as inositol hexakisphosphate, and $40 \%$ of the fractions were found as other forms of organic $\mathrm{P}$, which can be rapidly mineralized and become available to plants.
The $\mathrm{C}$ content in the humic fraction of the SOM was increased by Congo grass. Dry matter decomposition rates are generally slower in no-till compared to conventional tillage, in which the decomposition of SOM is hastened by revolving the soil and by alterations in the soil microclimate, and that is why no-till has been recommended as part of a strategy to reduce C loss from agricultural soils (Kern \& Johnson, 1993). Tyler et al. (1983) observed higher levels of organic matter in soybean plots under no-till, after two years, than under conventional tillage treatments.

In the present experiment, not only $\mathrm{C}$ and organic $\mathrm{P}$ increased under Congo grass, but the C:P ratio also increased. Worldwide, C:P ratios range from 60:1 to 186:1, and tend to be relatively stable (Zhang et al., 2013). Forages accumulate more $\mathrm{C}$ in soils, compared to grain crops, due to higher root biomass production (Salton et al., 2008; Franzluebbers, 2010). For cash and cover crops, the role of shoots and roots as sources of SOM has been the subject of several studies (Gale \& Cambardella, 2000), and it was suggested that rootderived $\mathrm{C}$ is the predominant contributor to soil organic C. Santos et al. (2011) reported that forage-based rotations of semi-perennial alfalfa and annual ryegrass for hay production contribute more to soil organic $\mathrm{C}$ sequestration than rotations based on cover crops (oat or vetch). The authors conclude that this can be explained by the roots, and either forage-based or cover crop-based rotations play a more relevant role in building up soil $\mathrm{C}$ stocks than shoot residues.

In humid tropical conditions, high critical C:P ratios are likely due to low decomposer phosphorus concentrations (Manzoni et al., 2010). Since phosphorus concentrations in plant residues tend to be low compared to the decomposer requirements, $\mathrm{P}$ may initially be immobilized by decomposers until the concentration in the residue reaches a critical value and net release occurs (Parton et al., 2007). The application of materials with wide $\mathrm{C}: \mathrm{P}$ ratios results in greater microbial biomass $\mathrm{P}$ concentrations, and a strong negative correlation between added $\mathrm{C}$ (and the $\mathrm{C}: \mathrm{P}$ ratio) and the increase in extractable $\mathrm{P}$ (Leytem et al., 2005). In the present experiment, the C:P ratio and the organic $\mathrm{P}$ bound to humic fractions were increased by Congo grass, in spite of an increase in readily available $\mathrm{P}$. This means that the grass, by adding large amounts of $\mathrm{C}$ to the soil, increased the demand for $\mathrm{P}$ decomposers, which may compete with the cash crop for soil $\mathrm{P}$ in the short range. In the long range, $\mathrm{P}$ from microbial biomass may become plant available.

\section{CONCLUSIONS}

1. Congo grass is responsive to $\mathrm{P}$ fertilization and increases residual inorganic $\mathrm{P}$ in the soil in the presence of $\mathrm{P}$ fertilizers. 
2. Growing Congo grass as a cover crop increases soil $\mathrm{C}$ pools, the $\mathrm{C}: \mathrm{P}$ ratio, and the $\mathrm{P}$ bound to humic acid.

3. In spite of the increased soil $\mathrm{P}$ lability after the introduction of Congo grass in the rotation, an increased C:P ratio will probably result in less $\mathrm{P}$ available for plants in the short term.

\section{LITERATURA CITED}

BOWMAN, R.A. \& COLE, C.V. An exploratory method for fractionation of organic phosphorus from grassland soils. Soil Sci.,125:95-101, 1978.

CAVIGELLI, M.A. \& THIEN, S.J. Phosphorus bioavailability following incorporation of green manure crops. Soil Sci. Soc. Am. J., 67:1186-1194, 2003.

CORRÊA, L.A. \& HAAG, H.P. Critical levels of phosphorus for the establishment of pasture grass on a Red Yellow Latossol: II. Field test. Sci. Agric., 50:109-116, 1993.

DALAL, R.C. Soil organic phosphorus. Adv. Agron., 29:83117, 1977.

EIVAZI, F. \& TABATABAI, M.A. Phosphatases in soils. Soil Biol. Biochem., 9:167-172, 1977.

ESSINGTON, M.E. \& HOWARD, D.D. Phosphorus availability and speciation in long-term no-till and disk-till soil. Soil Sci., 165:144-152, 2000.

FRANZLUEBBERS, A.J. Achieving soil organic carbon sequestration with conservation agricultural systems in the southeastern USA. Soil Sci. Soc. Am. J., 74:347-357, 2010 .

GALE, W.J. \& CAMBARDELLA, C.A. Carbon dynamics of surface residue- and root-derived organic matter under simulated no-till. Soil Sci. Soc. Am. J., 64:190-195, 2000.

GALVANI, R.; HOTTA, L.F.K. \& ROSOlEM, C.A. Phosphorus sources and fractions in an Oxisol under no-tilled soybean. Sci. Agric., 65:415-421, 2008.

GARCIA, R.A.; CRUSCIOL, C.A.C.; CALONEGO, J.C. \& ROSOLEM, C.A. Potassium cycling in a corn-brachiaria cropping system. Eur. J. Agron., 28:579-585, 2008.

GEORGE, T.S.; TURNER, B.L.; GREGORY, P.J.; CADEMENUN, B.J. \& RICHARDSON, A.E. Depletion of organic phosphorus from Oxisols in relation to phosphatase activities in the rhizosphere. Eur. J. Soil Sci., 57:47-57, 2006.

HEDLEY, M.J.; STEWART, J.W.B. \& CHAUHAN, B.S. Changes in inorganic and organic soil phosphorus fractions induced by cultivation practices and by laboratory incubations. Soil Sci. Soc. Am. J., 46:970-976, 1982.

HONG, J.K. \& YAMANE, I. Inositol phosphate and inositol humic acid and fulvic acid fractions extracted by three methods. Soil Sci. Plant Nutr., 26:491-496, 1980.
IVANOFF, D.B.; REDDY, K.R. \& ROBINSON, S. Chemical fractionation of organic phosphorus in selected Histosols. Soil Sci., 163:36-45, 1998.

JANEGITZ, M.C.; INOUE, B.S. \& ROSOLEM, C.A. Formas de fósforo no solo após o cultivo de braquiária e tremoçobranco. Ci. Rural, 43:1381-1386, 2013.

KERN, J.S. \& JOHNSON, M.G. Conservation tillage impacts on national soil and atmospheric carbon levels. Soil Sci. Soc. Am. J., 57:200-210, 1993.

KLOSE, S. \& TABATABAI, M.A. Response of phosphomono esterases in soils to chloroform fumigation. J. Plant Nutr. Soil Sci., 165:429-434, 2002.

KWABIAH, A.B.; PALM, C.A.; STOSKOPF, N.C. \& VORONEY, R.P. Response of soil microbial biomass dynamics to quality of plant materials with emphasis on P availability. Soil Biol. Biochem., 35:207-216, 2003.

LEYTEM, A.B.; TURNER, B.L.; RABOY, V. \& PETERSON, L. Linking manure properties to phosphorus solubility in calcareous soils: Importance of the manure carbon to phosphorus ratio. Soil Sci. Soc. Am. J., 69:1516-1524, 2005.

LOUW-GAUME, A.E.; RAO, M.I.; GAUME, A.J. \& FROSSARD, E. A comparative study on plant growth and root plasticity responses of two Brachiaria forage grasses grown in nutrient solution at low and high phosphorus supply. Plant Soil, 328:155-164, 2010.

LUPWAYI, N.Z.; CLAYTON, G.W.; O’DONOVAN, J.T.; HARKER, K.N.; TURKINGTON, T.K. \& RICE, W.A. Decomposition of crop residues under conventional and zero tillage. Can. J. Soil Sci., 84:403-410, 2004.

MAKAROV, M.I.; GUGGENBERGER, G.; ZECH, W. \& ALT, H.G. Organic phosphorus species in humic acids of mountain soils along a toposequence in the Northern Caucasus. J. Plant Nutr. Soil Sci.,159:467-470, 1996.

MANZONI, S.; TROFYMOW, J.A.; JACKSON, B.R. \& PORPORATO, A. Stoichiometric controls on carbon, nitrogen, and phosphorus dynamics in decomposing litter. Ecol. Monogr., 80:89-106, 2010.

MERLIN, A.; ROSOLEM, C.A. \& BÜLL, J.C.L. Soil phosphorus forms after brachiaria. In: INTERNATIONAL PLANT NUTRITION COLLOQUIUM, 16., Davis, 2009. Proceedings... Davis, University of California, 2009. Available at: <http://repositories.cdlib.org/ipnc/xvi/1169>.

MURPHY, J. \& RILEY, J.P. A modified single solution method for the determination of phosphate in natural waters. Anal. Chim. Acta, 27:31-36, 1962.

NAHAS, E. Microrganismos do solo produtores de fosfatases em diferentes sistemas agrícolas. Bragantia, 61:267-275, 2002 .

PARTON, W.J.; STEWART, B. \& COLE, C.V. Dynamics of C, N, P and S in grassland soils: A model. Biogeochemistry, 5:109-131, 1988 .

RAIJ, B.van; QUAGGIO, J.A. \& SILVA, N.M. Extraction of phosphorus, potassium, calcium, and magnesium from soils by an ion exchange resin procedure. Commun. Soil Sci. Plant Anal., 17:547-566, 1986. 
REDDY, D.D.; RAO, A.S. \& SINGH, M. Crop residue addition effects on myriad forms and sorption of phosphorus in a Vertisol. Bioresour. Technol., 80:93-99, 2001.

SALTON, J.C.; MIELNICZUK, J.; BAYER, C.; BOENI, M.; CONCEIÇÃO, P.C. \& AMOACY, C.F. Agregação do solo e estabilidade de agregados sob sistemas lavoura-pecuária no Mato Grosso do Sul, Brasil. R. Bras. Ci. Solo, 32:11-21, 2008.

SANTOS, N.Z.; DIECKOW, J.; BAYER, C.; MOLIN, R.; FAVARETTO, N.; PAULETTI, V. \& PIVA, J.T. Forages, cover crops and related shoot and root additions in no-till rotations to $\mathrm{C}$ sequestration in a subtropical Ferralsol. Soil Till. Res., 111:208-218, 2011.

SAS Institute. SAS user's guide: Statistics. Cary, 2001.

SHARPLEY, A.N. \& SMITH, S.J. Fractionation of inorganic and organic phosphorus in virgin and cultivated soils. Soil Sci. Soc. Am. J., 49:127-130, 1985.

SOIL SURVEY STAFF. Keys to soil taxonomy, 11.ed. Washington, USDA/NRCS, 2010.

TARAFDAR, J.C. \& CLAASSEN, N. Organic phosphorus compounds as a phosphorus source for higher plants through the activity of phosphatases produced by plant roots and microorganisms. Biol. Fertil. Soils, 5:308-312, 1988.
TARAFDAR, J.C. Use of electrofocussing technique for characterizing the phosphatases in the soil and root exudates. J. Ind. Soc. Soil Sci., 37:393-395, 1989.

TYLER, D.D.; OVERTON, J.R. \& CHAMBERS, A.Y. Tillage effects on soil properties, diseases, cyst nematodes, and soybean yields. J. Soil Water Conserv., 38:374-376, 1983.

WAIGWA, M.W.; OTHIENO, C.O. \& OKALEBO, J.R. Phosphorus availability as affected by the application of phosphate rock combined with organic materials to acid soils in western Kenya. Exp. Agric., 39:395-407, 2003.

WATTS, M. \& EVANS, J.R. Phosphorus acquisition from soil by white lupin (Lupinus albus L.) and soybean (Glycine $\max$ L.), species with contrasting root development. Plant Soil, 248:271-283, 2003.

WHITBREAD, A.M.; BLAIR, G.J. \& LEFROY, R.D.B. Managing legume leys, residues and fertilizers to enhance the sustainability of wheat cropping systems in Australia. 2. Soil physical fertility and carbon. Soil Till. Res., 54:77-89, 2000.

ZHANG, Z.; SONG, X.; LU, X. \& XUE, Z. Ecological stoichiometry of carbon, nitrogen, and phosphorus in estuarine wetland soils: Influences of vegetation coverage, plant communities, geomorphology, and seawalls. J. Soils Sed., 13:1043-1051, 2013. 